\title{
Customer Loyalty During Pandemic: Understanding Loyalty Through the Lens of Online Ride Hailing Service Quality
}

\author{
Katon Pratondo ${ }^{1 *}$, Zaid $^{2}$ \\ ${ }^{1}$ Veteran National Development University of Yogyakarta, DIY, Indonesia \\ ${ }^{2}$ Muhammadiyah University of Yogyakarta, DIY, Indonesia
}

\author{
A R T I C L E I N F O \\ Article history: \\ Received 08 January 2021 \\ Received in revised form \\ 15 January 2021 \\ Accepted 10 February 2021 \\ Available online 25 \\ February 2021 \\ Keywords: \\ Service Quality, \\ Customer Delight, Customer \\ Loyalty
}

\begin{abstract}
A B S T R A C T
This research study aimed to research and analyze the influence of service quality on customer loyalty mediated by customer delight on online ride hailing industry in D.I. Yogyakarta. This research method used quantitative analysis involving data taken using a purposive sampling technique to collect the data from 128 online ride hailing customers in D.I. Yogyakarta with certain criteria as a sample. The sample data was then collected through a survey by using a questionnaire distributed to respondents. The data that had been obtained then analyzed through regression analysis, and path analysis by using the SPSS Statistics 25 program. The result of this study indicated that while service quality had positive influence on customer delight and customer loyalty. Customer delight also had a positive influence on customer loyalty, and at the same time played an important role in mediating the influence of service quality on customer loyalty. This study indicates that service quality plays an important and becomes the key role in influencing customer delight which is at the same time is an important factor in gaining customer loyalty in online ride hailing industry. Besides service quality, it turns out that customer Delight also has a positive influence on customer loyalty. and as a mediator, its role in mediating service quality on customer loyalty is also proven to be effective.
\end{abstract}

Copyright (C) Universitas Pendidikan Ganesha. All rights reserved.

\section{Introduction}

Currently, the whole world is experiencing a crisis caused by Corona Virus Disease 19 or COVID19. The COVID-19 pandemic is an unprecedented extraordinary crisis (Athique, 2020; Mehta et al., 2020) that has caused both the activities and the environment in the market crash (Smales, 2020) decrease the growth of national economic till to affect public welfare in Indonesia. Therefore, the Indonesian government through Government Regulation Number 21 of 2020 implemented Large-Scale Social Restrictions (PSBB) in the Context of Accelerating Handling of Corona Virus Disease 2019 (Covid-19).

But unfortunately, this rule gave a huge impact on the business world in Indonesia. The International Labor Organization (ILO) noted that around 65\% of the business world in Indonesia was directly affected by the Covid-19 pandemic. As many as $2.6 \%$ of companies actually stop their operations permanently. Meanwhile, 62.2\% stopped operating temporarily, and the remaining 3\% had started operating again. And even those businesses that still survive are inseparable from the bad effects of covid19. The results of a survey conducted by the Central Statistics Agency recorded that $82.85 \%$ of entrepreneurs experienced a decline in income due to the Covid-19 pandemic. The decline in income was mostly experienced by small and medium enterprises, reaching 84\%, compared to medium and large businesses, which reached $82 \%$. And the companies that have the most impact are those in the service sector. One of them is the online ride hailing company.

Realizing this, the government then slightly loosened the PSBB by implementing a new normal to ensure that the economy was running again. Although COVID-19 has changed service operations and service marketing (Berry et al., 2020), This was definitely big opportunity (Ul Haq \& Awan, 2020) and a breath of fresh air for service industries especially online ride haling companies to get back up and get a profit. One of the most effective strategies to make this happen is to create customer loyalty (Sandada \& 
Matibiri, 2016). Customer loyalty is described and defined as customer's decision to to maintain relationships with service providers (Sindwani \& Goel, 2015) continue using or purchasing and repurchasing a company's services (Fida et al., 2020; Morgeson et al., 2020).

Customer loyalty has undoubtedly become an important element and the main concern for the company (Boakye et al., 2017). It can be beneficially obtained in a way to improve service quality as proven on the empirical researches (Lai, 2014; Lemy et al., 2019; Lin et al., 2016; Nguyen-Phuoc et al., 2020). Furthermore, service quality that is defined as consumers' perceptions as well as expectations before receiving services and, the means by which services are provided simultaneously, has very strong influence on (Al-Hawari, 2011; Elias-Almeida et al., 2016; Torres \& Kline, 2006) and the very close relationship (Choi et al., 2019; Kao et al., 2016; Wattanakamolchai et al., 2016) with customer delight which has been proved in some research literature (Ahrholdt et al., 2016; Joudeh \& Dandis, 2018; Wang, 2011).

Customer delight is simply a positive emotional response be composed of overjoy and surprise of pleasant (Rust \& Oliver, 1994; Schnebelen \& Bruhn, 2018) when the value and benefit of delivered services or products beyond their expectations (Foroughi et al., 2019; Loureiro \& Kastenholz, 2011; Stock et al., 2016), satisfaction (Chandler, 1989; Parasuraman et al., 1988). Based on that ideas, customer delight associate to but is not analogous and different from customer satisfaction (Jin et al., 2016; Rust \& Oliver, 1994), because it not only requires stronger positive emotions (Magnini et al., 2011), but also different physiological states (Stock et al., 2016). Satisfied customers are not always excited about a company; they just feel comfortable. Furthermore, delighted customers have greater recognition and enjoyment to the company (Paul, 2000).

Just like service quality, customer delight is also a variable that influences customer loyalty. Several researchers have proven that delighting customers has positive relationship (Jiang, 2019; Kim, 2011; Mahadin et al., 2020) and is also the best way to generate, develop and improve customer loyalty (Ahrholdt et al., 2016; Crotts \& Magnini, 2011; Foroughi et al., 2019; Lari et al., 2019; Su et al., 2019)and willingness to recommend (Jiang, 2019; Loureiro \& Kastenholz, 2011). Even in several other studies show that customer delight is a key mediator for service quality in influencing customer loyalty (Foroughi et al., 2019; Rust \& Oliver, 1994). Then, based on that exposure, it is a must for companies to be customeroriented by designing experiences that are more enjoyable than just satisfying customers to win increasingly smart and knowledgeable customer loyalty (Andreassen et al., 2016). To satisfy customers and build consumer loyalty to get new productive customers, customer delight is a very important issue. Customer loyalty can be achieved when customers are so pleased with the service quality that is provided.

The study of the antecedents of customer delight and loyalty of ride hailing service is still very limited and has not been well researched in the transportation behavior literature (Nguyen-Phuoc et al., 2020). So that, this study aims to analyze and ascertain the influence of service quality on customer delight (H1), service quality on customer loyalty (H2), customer delight on customer loyalty (H3). This study also aims to identify the role of customer delight in mediating the influence of service quality on customer loyalty (H4). In order that there is no expansion of the problem that is not in accordance with the objective of this study, then this study only focuses on the analysis of online ride hailing consumer behavior in D.I. Yogyakarta in the amid of the Covid-19 pandemic.

\section{Methods}

This study is a quantitative study involving data taken using a purposive sampling technique on 128 online ride hailing customers in D.I. Yogyakarta with the criteria of being domiciled in the city of Yogyakarta (42.97\%), Sleman (28.13\%), Bantul (14.06\%), Gunung Kidul (3.91\%), and Kulonprogo Regency (10.94\%). In addition, the intended respondents must also be adult's male (36.72\%) and female $(63.28 \%)$ who are marked as 17 years old or more, and have used online ride-hailing services at least 2 times to adjust to the loyalty variable. The sample data is then gathered by questionnaire that is distributed online to respondents who were surveyed via google form which is circulated through social media platforms such as WhatsApp, email, Facebook, and Instagram. The distribution of questionnaires started at the beginning of the implementation of the new normal (Wajar Anyar) in D.I. Yogyakarta in July 2020.

The distributed questionnaire has been adjusted to the constructs of each variable. In the service quality variable, the construct used includes ten items offered by (Parasuraman et al., 1988) in the form of tangibles, security, understanding the consumer, reliability, credibility, courtesy, communication, responsiveness, competence, and accessibility. each construct on this variable uses one instrument.

In the customer delight variable, the constructs used include five items which are delighted, gleeful, and elated (Finn, 2005), Joy and positive surprise (Barnes et al., 2016; Rust \& Oliver, 1994). each 
construct on this variable uses two instruments so that the total becomes ten instruments. While the customer loyalty variable, the construct used in this study uses (Griffin, 2005) four measurement items in the form of repeated purchases, purchases outside the product/service line, positive word of mouth, and does not want to turn to competitors. each construct on this variable uses two instruments so that the total becomes eight instruments. The data that has been obtained is then processed using the SPSS Statistics 25 program.

The data analysis techniques used is simple regression analysis that is used to analyze the direct influence of both service qualities on customer delight and customer loyalty as well as the direct effect of customer delight on customer loyalty. And also path analysis that is used to analyze the influence and the role of customer delight in mediating the influence of service quality on customer loyalty through Sobel test

\section{Results and Discussions}

The results of data processing using SPSS Statistics 25 show that all indicators of service quality $(\mathrm{X})$, customer delight $(\mathrm{Z})$, and customer loyalty $(\mathrm{Y})$ are declared valid and reliable. A measurement instrument can be declared valid if the Pearson correlation value $>r$ table with a significant level of $5 \%$ (Ghozali, 2011) and a constructor variable is considered to be reliable if the result of Cronbach Alpha value is $>0.70$ (Sugiyono, 2019). From the results shown in Table 1, it can be referred that all values of correlation $>\mathrm{r}$ table $(0.173)$ and in Table 2 show the value of Cronbach Alpha $>0.70$. Thus, all statement items can be declared valid and reliable.

Table 1. Validity test results

\begin{tabular}{|c|c|c|c|c|c|}
\hline Variable & Instrument & Pearson Correlation & R Table & Significance & Validity Status \\
\hline \multirow[t]{10}{*}{ SQ $(X)$} & X.1 & 0.651 & 0.173 & 0.000 & Valid \\
\hline & $\mathrm{X} .2$ & 0.609 & 0.173 & 0.000 & Valid \\
\hline & X.3 & 0.632 & 0.173 & 0.000 & Valid \\
\hline & $\mathrm{X} .4$ & 0.531 & 0.173 & 0.000 & Valid \\
\hline & X.5 & 0.433 & 0.173 & 0.000 & Valid \\
\hline & X.6 & 0.524 & 0.173 & 0.000 & Valid \\
\hline & X.7 & 0.565 & 0.173 & 0.000 & Valid \\
\hline & X.8 & 0.528 & 0.173 & 0.000 & Valid \\
\hline & X.9 & 0.558 & 0.173 & 0.000 & Valid \\
\hline & X.10 & 0.545 & 0.173 & 0.000 & Valid \\
\hline \multirow[t]{10}{*}{$\mathrm{CD}(\mathrm{Z})$} & $\mathrm{Z} .1$ & 0.736 & 0.173 & 0.000 & Valid \\
\hline & $\mathrm{Z} .2$ & 0.703 & 0.173 & 0.000 & Valid \\
\hline & $\mathrm{Z} .3$ & 0.668 & 0.173 & 0.000 & Valid \\
\hline & Z.4 & 0.678 & 0.173 & 0.000 & Valid \\
\hline & Z.5 & 0.622 & 0.173 & 0.000 & Valid \\
\hline & Z.6 & 0.611 & 0.173 & 0.000 & Valid \\
\hline & Z.7 & 0.643 & 0.173 & 0.000 & Valid \\
\hline & Z.8 & 0.699 & 0.173 & 0.000 & Valid \\
\hline & Z.9 & 0.704 & 0.173 & 0.000 & Valid \\
\hline & Z.10 & 0.706 & 0.173 & 0.000 & Valid \\
\hline \multirow[t]{8}{*}{ CL (Y) } & Y.1 & 0.712 & 0.173 & 0.000 & Valid \\
\hline & Y.2 & 0.762 & 0.173 & 0.000 & Valid \\
\hline & Y.3 & 0.746 & 0.173 & 0.000 & Valid \\
\hline & Y.4 & 0.670 & 0.173 & 0.000 & Valid \\
\hline & Y.5 & 0.612 & 0.173 & 0.004 & Valid \\
\hline & Y.6 & 0.509 & 0.173 & 0.029 & Valid \\
\hline & Y.7 & 0.590 & 0.173 & 0.000 & Valid \\
\hline & Y.8 & 0.636 & 0.173 & 0.000 & Valid \\
\hline
\end{tabular}

Table 2. Reliability test results 


\begin{tabular}{lll}
\hline Variable/ indicator & Cronbach's alpha & Reliable Status \\
\hline SQ & 0.755 & Reliable \\
CD & 0.869 & Reliable \\
CL & 0.811 & Reliable \\
\hline
\end{tabular}

The results of testing the analysis of the influence of service quality on customer delight are presented in Table 3.

Table 3. Regression analysis results of service quality on customer delight

\begin{tabular}{|c|c|c|c|c|c|}
\hline \multicolumn{6}{|c|}{ Coefficients } \\
\hline \multirow[t]{2}{*}{ Model } & \multicolumn{2}{|c|}{$\begin{array}{c}\text { Unstandardized } \\
\text { Coefficients }\end{array}$} & \multirow{2}{*}{$\begin{array}{c}\begin{array}{c}\text { Standardized } \\
\text { Coefficients }\end{array} \\
\text { Beta } \\
\end{array}$} & \multirow[t]{2}{*}{$\mathbf{t}$} & \multirow[t]{2}{*}{ Sig. } \\
\hline & B & Std. Error & & & \\
\hline (Constant) & 19.206 & 3.682 & & 5.217 & 0 \\
\hline Customer Loyalty & 0.367 & 0.118 & 0.267 & 3.115 & 0.002 \\
\hline
\end{tabular}

Based on Table 3, it can be refered that the regression equation obtained:

$$
\mathrm{Z}=19.206+0.367 \mathrm{X}
$$

The results of testing the analysis of the influence of service quality and customer delight on customer loyalty are presented in Table 4 below:

Table 4. Dependen Regression analysis results of service quality and customer delight on customer loyalty

\begin{tabular}{|c|c|c|c|c|c|}
\hline \multicolumn{6}{|c|}{ Coefficients $^{\mathbf{a}}$} \\
\hline \multirow[t]{2}{*}{ Model } & \multicolumn{2}{|c|}{$\begin{array}{l}\text { Unstandardized } \\
\text { Coefficients }\end{array}$} & \multirow{2}{*}{$\begin{array}{l}\text { Standardized } \\
\text { Coefficients } \\
\text { Beta } \\
\end{array}$} & \multirow[t]{2}{*}{$\mathbf{t}$} & \multirow[t]{2}{*}{ Sig. } \\
\hline & B & Std. Error & & & \\
\hline (Constant) & 11.334 & 3.052 & & 3.713 & 0.000 \\
\hline Service Quality & 0.266 & 0.092 & 0.246 & 2.9 & 0.004 \\
\hline Customer Delight & 0.209 & 0.067 & 0.264 & 3.114 & 0.002 \\
\hline
\end{tabular}

Based on Table 4, it can be referred that the regression equation obtained:

$$
\mathrm{Y}=11.334+0.266 \mathrm{X}+0.209 \mathrm{Z} €
$$

The next step in path analysis is to interpret the results of the analysis. Based on Table 3 about the influence of service quality on customer delight, the results show that the regression coefficient of service quality variables has a positive influence on customer delight of 0.367 with $0.002<0.05$ significance level. Based on Table 4, the influence of service quality and customer delight on customer loyalty shows that the regression coefficient of service quality variables has a positive influence on customer loyalty of 0.266 with a significance level of $0.004<0.05$. While service quality also has an influence on customer loyalty of 0.209 with a significance level of $0.002<0.05$.

In addition, this study also tries to examine the indirect influence of service quality on customer loyalty. Testing the role of customer delight in mediating service quality on customer loyalty uses the ttest statistic with the Sobel test below:

$$
\begin{aligned}
& \mathrm{SP}_{2} \mathrm{P}_{3}=\sqrt{{P_{a}}^{2} S P_{2}{ }^{2}+P_{2}{ }^{2} S P_{\mathrm{a}}{ }^{2}+S P_{2}{ }^{2} S P_{\mathrm{a}}{ }^{2}} \\
& \mathrm{SP}_{2} \mathrm{P}_{3}=\sqrt{(0,209)^{2}(0,118)^{2}+(0,367)^{2}(0,067)^{2}+(0,118)^{2}(0,067)^{2}} \\
& \mathrm{SP}_{2} \mathrm{P}_{3}=0,0357
\end{aligned}
$$

Based on the results of $\mathrm{SP}_{3} \mathrm{P}_{5}$, the $t$ statistic value of the mediation influence can be calculated by the following formula:

$$
\mathrm{T}_{\text {count }}=\frac{\frac{P_{2} P_{3}}{\sum_{p_{2} P_{3}}}}{\mathrm{~T}_{\text {count }}=\frac{[0,367\})(0,209)}{0,0357}}
$$


$\mathrm{T}_{\text {count }}=2.147$

From the above calculations, it shows that the value of t-test is $2.147>1.97897$ (t-table) with a significance level of 0.05 . Thus, it can be stated and concluded that service quality has a significant indirect influence on customer loyalty with customer delight as a mediating variable.

\section{Discussion}

As already mentioned, the studies on the antecedents of customer delight and loyalty of ride hailing are still very limited and have not been well studied in the literature on transportation behavior. In customer-oriented era, to any service companies especially online ride hailing service company, the matters of how to manage, maintain, and improve the effective service in order to keep current customers and gain potential customer is the main issue for its sustainability. This study reveals some theoretical implications for consumer behavior research as one of the few empirical studies in the context of online ride-hailing services. The findings of this study broaden the study and knowledge of service quality of online ride hailing, customer delight, and loyalty, while providing a foundation for researchers to understand the effects of service quality, joy, and loyalty. Based on the result of the research data above, it shows that each variable influence and supports one another.

First, it appears that service quality as perceived or hypothesized in this study has a positive $(0.367)$ and significant $(0.002<0.05)$ influence on customer delight. This evidence suggests that delight emerges, as hypothesized, as an overall evaluation that refers to an entire quality assessment of the relevant dimensions and associated service attributes. this result supports inline previous empirical research (Ahrholdt et al., 2016; Al-Hawari, 2011; Elias-Almeida et al., 2016; Joudeh \& Dandis, 2018; Torres \& Kline, 2006; Wang, 2011). This result implies that the service extent that is served to the customer can make a positive and significant influence on their delight in terms of enchanting them to the service and delight them with the level of the service that beyond they expect. Thus, even in the midst of a pandemic like this time, online ride-hailing service companies operating in D.I. Yogyakarta have made great efforts to increase the scope of the technical aspects of the service such as good physical appearance of the car or motorbike, assurance of security, understanding, reliability, credibility, courtesy, response, competence, and accessibility, and communication to get the services provided to customers with excellent and delightful responses. therefore, these findings suggest that online ride hailing companies in D.I. Yogyakarta should pay more attention and continue to develop these aspects better and manage them effectively. If the online ride hailing company in D.I. Yogyakarta lacks one of these aspects or there are problems with this aspect, so this will have implications for customer delight.

Second, it appears that customer delight as perceived or hypothesized in this study has a positive $(0.266)$ and significant $(0.004<0.05)$ influence on customer loyalty. This evidence suggests that loyalty emerges, as hypothesized, as an overall evaluation that refers to an overall delight assessment of the relevant dimensions and associated delight attributes. This result also supports inline previous empirical research (Ahrholdt et al., 2016; Crotts \& Magnini, 2011; Foroughi et al., 2019; Lari et al., 2019; Su et al., 2019). So then, the result of this study points that when customers of online ride hailing in D.I. Yogyakarta feel delightful, then they are happily going to be loyal customers. Indeed, loyalty in tis study expressed by repeated purchases, purchases outside the product/service line, positive word of mouth, and does not want to turn to competitors. Although traditionally, many researchers argued that the important antecedent of loyalty is customer satisfaction. However, customer delight may be a more effective antecedent (Lari et al., 2019). It is exactly like (Torres et al., 2014) said that customer delight seems to occur as a result of feelable, reproducible, and positive memorable events that has a stronger influence on customer loyalty than satisfaction.

Third, it appears that service quality as perceived or hypothesized in this study has a positive (0.367) and significant $(0.002<0.05)$ influence on customer loyalty. As a result, a clear influence between service quality and loyalty has been confirmed in this study. So then, the result of this study points that when the quality of services delivered by online ride hailing companies in D.I. Yogyakarta is high and positive, it will increase customer loyalty. On the contrary, when the quality of services delivered by online ride hailing companies in D.I. Yogyakarta is low and negative, it will decrease customer loyalty. This evidence suggests that as long as online ride hailing companies in D.I. Yogyakarta manage, maintai, and improve their service quality, customers will not hesitate to make repeat purchases, they will also be happy to buy outside the product/service line, voluntarily promote positive word of mouth, and even they dare to guarantee not to switch to competitors. However, this result also supports previous empirical research (Lai, 2014; Lemy et al., 2019; Lin et al., 2016; Nguyen-Phuoc et al., 2020).

Fourth, it appears that customer delight as perceived or hypothesized in this study can significantly mediates (2.147 [t-test] $>1.97897$ [ $\mathrm{t}$ table]) the influence of service quality on customer 
loyalty. This means that the developed hypothesis 4 in this article which states that "customer delight is able to mediate the influence of service quality on customer loyalty" is accepted, this result also supports previous empirical research (Foroughi et al., 2019; Rust \& Oliver, 1994). So then, this finding implies that although service quality is the main key influencing consumer loyalty, it turns out that customer delight also plays an important role in mediating the influence between the two of them. meaningly, the influence between service quality and customer loyalty will be much stronger and more positive with the presence of customer pleasure. So, when customers are happy with the quality of service provided by an online ride-hailing company, it will definitely make customers much more loyal.

However, There are some particular limitations of the study that have to be acknowledged. This study only focuses on online ride hailing companies operating in D.I. Yogyakarta in the condition and situation of the Covid-19 pandemic. Besides that the respondents who participated were only 128 respondents who had been determined purposively by the researchers. Therefore, caution must be carefully employed in generalizing the findings of this study. Notwithstanding the limitations, this study presents obvious evidence in the online ride hailing context that good quality in service is required to be given more importance because it is the main drivers of customer loyalty. But, delighted customer aspects cannot be neglected because they promote and lead to loyalty as well. they even mediated the influence of service quality on customer loyalty. Nevertheless, This study also suggests that further studies are required to examine the successive direct and indirect influence between service quality, customer delight, and also customer loyalty.

\section{Conclusion}

Based on the results and discussion of the research above, the conclusion in this study is that this study supports as well as empirical evidence for theories regarding the positive influence between service quality, customer delight, and customer loyalty. This study indicates that service quality plays an important and becomes the key role in influencing customer delight which is at the same time is an important factor in gaining customer loyalty in online ride hailing industry. Besides service quality, it turns out that customer Delight also has a positive influence on customer loyalty. and as a mediator, its role in mediating service quality on customer loyalty is also proven to be effective. At the end with limitations and shortcomings, and for the sake of developing existing theories and contributing to empirical research. the author suggests other researchers to try to re-examine the influence of service quality, customer delight, and customer loyalty in other sectors and industries. Or also using other variables using different methods and approaches. because the author believes that there are still many variables and approaches that can be used in developing service quality, especially in-service industries that are struggling to survive amid the conditions of the Covid-19 crisis. And for online ride hailing companies, especially those operating in D.I Yogyakarta, to manage, maintain and improve the quality of their services, which has become a key factor in getting customer delight which will ultimately win customer loyalty. So it is hoped that even in the midst of the Covid-19 crisis, the company can still survive and even continue to get profit and benefit from high customer loyalty.

\section{References}

Ahrholdt, D. C., Gudergan, S. P., \& Ringle, C. M. (2016). Enhancing Service Loyalty. Journal of Travel Research, 56(4), 436-450. https://doi.org/10.1177/0047287516649058.

Al-Hawari, M. A. (2011). Automated service quality as a predictor of customers' commitment. Asia Pacific $\begin{array}{llll}\text { Journal of } \quad \text { Marketing } & \text { 346-366. }\end{array}$ https://doi.org/10.1108/13555851111143259.

Andreassen, T. W., Kristensson, P., Lervik-Olsen, L., Parasuraman, A., McColl-Kennedy, J. R., Edvardsson, B., \& Colurcio, M. (2016). Linking service design to value creation and service research. Journal of Service Management, 27(1), 21-29. https://doi.org/10.1108/josm-04-2015-0123.

Athique, A. (2020). Extraordinary issue: Coronavirus, crisis and communication. Media International Australia, 177(1), 3-11. https://doi.org/10.1177/1329878X20960300.

Barnes, D. C., Collier, J. E., Howe, V., \& Douglas Hoffman, K. (2016). Multiple paths to customer delight: The impactof effort, expertise and tangibles on joy and surprise. Journal of Services Marketing, 30(3), 277-289. https://doi.org/10.1108/JSM-05-2015-0172.

Berry, L. L., Danaher, T. S., Aksoy, L., \& Keiningham, T. L. (2020). Service Safety in the Pandemic Age. Journal of Service Research, 23(4), 391-395. https://doi.org/10.1177/1094670520944608. 
Boakye, K. G., Blankson, C., \& Prybutok, V. R. (2017). The Battle for Customer Loyalty: An Examination of Customer Loyalty in the Goods and Services Domain. Quality Management Journal, 24(4), 21-34. https://doi.org/10.1080/10686967.2017.12088377.

Chandler, C. C. (1989). Specific retroactive interference in modified recognition tests: Evidence for an unknown cause of interference. Journal of Experimental Psychology: Learning, Memory, and Cognition, 15(2), 256-265. https://doi.org/10.1037/0278-7393.15.2.256.

Choi, L., Lawry, C. A., \& Kim, M. (2019). Contextualizing customer organizational citizenship behaviors: The changing nature of value cocreation and customer satisfaction across service settings. Psychology \& Marketing, 36, 455-472. https://doi.org/10.1002/mar.21190.

Crotts, J. C., \& Magnini, V. P. (2011). The customer delight construct: is surprise essential? Annals of Tourism Research, 38(2), 719-722. https://doi.org/10.1016/J.ANNALS.2010.03.004.

Elias-Almeida, A., Miranda, F. J., \& Almeida, P. (2016). Customer delight: perception of hotel spa consumers. European Journal of Tourism, Hospitality and Recreation, 7(1), 13-20. https://doi.org/10.1515/ejthr-2016-0002.

Fida, B. A., Ahmed, U., Al-Balushi, Y., \& Singh, D. (2020). Impact of Service Quality on Customer Loyalty and Customer Satisfaction in Islamic Banks in the Sultanate of Oman. SAGE Open, 10(2), 1-10. https: //doi.org/10.1177/2158244020919517.

Finn, A. (2005). Reassessing the foundations of customer delight. Journal of Service Research, 8(2), 103116. https://doi.org/10.1177/1094670505279340.

Foroughi, B., Iranmanesh, M., Gholipour, H. F., \& Hyun, S. S. (2019). Examining relationships among process quality, outcome quality, delight, satisfaction and behavioural intentions in fitness centres in Malaysia. International Journal of Sports Marketing and Sponsorship, 20(3), 374-389. https://doi.org/10.1108/ijsms-08-2018-0078.

Ghozali, I. (2011). Aplikasi Analisis Multivariate dengan Program IBM SPSS 19 (5th ed.). UNDIP.

Griffin, J. (2005). Customer Loyalty: Menumbuhkan \& Mempertahankan Kesetiaan Pelanggan (1st ed.). Erlangga.

Jiang, Y. (2019). A Cognitive Appraisal Process of Customer Delight: The Moderating Effect of Place Identity. Journal of Travel Research, 59(6), 1029-1043. https://doi.org/10.1177/0047287519872827.

Jin, N. (Paul), Line, N. D., \& Merkebu, J. (2016). The effects of image and price fairness. International Journal of Contemporary Hospitality Management, 28(9), 1895-1915. https://doi.org/10.1108/ijchm-032015-0094.

Joudeh, J. M. M., \& Dandis, A. O. (2018). Service Quality, Customer Satisfaction and Loyalty in an Internet Service Providers. International Journal of Business and Management, 13(8), 108. https://doi.org/10.5539/ijbm.v13n8p108.

Kao, C.-Y., Tsaur, S.-H., \& Wu, T.-C. (2016). Organizational culture on customer delight in the hospitality industry. International Journal of Hospitality Management, 56, 98-108. https://doi.org/10.1016/j.ijhm.2016.05.001.

Kim, M. R. (2011). The importance of customer satisfaction and delight on loyalty in the tourism and hospitality industry. European Journal of Tourism Research, 4(2), 226-228. https://ejtr.vumk.eu/index.php/about/article/download/79/80.

Lai, I. K. W. (2014). The Roles of Value, Satisfaction, and Commitment in the Effect of Service Quality on Customer Loyalty in Hong Kong-Style Tea Restaurants. Cornell Hospitality Quarterly, 56(1), 118138. https://doi.org/10.1177/1938965514556149.

Lari, L. A. D. A., Iyanna, S., \& Jabeen, F. (2019). Islamic and Muslim tourism: service quality and theme parks in the UAE. Tourism Review, 75(2), 402-413. https://doi.org/10.1108/tr-05-2018-0062.

Lemy, D., Goh, E., \& Ferry, J. (2019). Moving out of the silo: How service quality innovations can develop customer loyalty in Indonesia's hotels. Journal of Vacation Marketing, 25(4), 462-479. https: //doi.org/10.1177/1356766718819658.

Lin, S.-P., Yang, C.-L., Pi, H.-C., \& Ho, T.-M. (2016). Tourism guide cloud service quality: What actually delights customers? SpringerPlus, 5(1), 1-9. https://doi.org/10.1186/s40064-016-3345-4.

Loureiro, S. M. C., \& Kastenholz, E. (2011). Corporate reputation, satisfaction, delight, and loyalty towards rural lodging units in Portugal. International Journal of Hospitality Management, 30(3), 575-583. https://doi.org/10.1016/j.ijhm.2010.10.007. 
Magnini, V. P., Crotts, J. C., \& Zehrer, A. (2011). Understanding Customer Delight: An Application of Travel Blog Analysis. Journal of Travel Research, 50(5), 535-545. https://doi.org/10.1177/0047287510379162.

Mahadin, B., Akroush, M. N., \& Bata, H. (2020). The effects of tourism websites' attributes on satisfaction and e-loyalty: a case of American travellers' to Jordan. International Journal of Web Based Communities, 16(1), 4-22. https://doi.org/10.1504/ijwbc.2020.105124.

Mehta, S., Saxena, T., \& Purohit, N. (2020). The New Consumer Behaviour Paradigm amid COVID-19: Permanent or Transient? Journal of Health Management, 22(2), 291-301. https://doi.org/10.1177/0972063420940834.

Morgeson, F. V., Hult, G. T. M., Mithas, S., Keiningham, T., \& Fornell, C. (2020). Turning Complaining Customers into Loyal Customers: Moderators of the Complaint Handling-Customer Loyalty Relationship. Journal of Marketing, 84(5), 79-99. https://doi.org/10.1177/0022242920929029.

Nguyen-Phuoc, D. Q., Su, D. N., Tran, P. T. K., Le, D.-T. T., \& Johnson, L. W. (2020). Factors influencing customer's loyalty towards ride-hailing taxi services - A case study of Vietnam. Transportation Research Part A: Policy and Practice, 134, 96-112. https://doi.org/10.1016/j.tra.2020.02.008.

Parasuraman, A., Zeithaml, V. A., \& Berry, L. L. (1988). Servqual : A Multiple-Item Scale for Measuring Consumer Perceptions of Service Quality. Journal of Retailing, 64(1).

Paul, J. (2000). Are you delighting your customers? Non-Profit World, 18(5), 34-36. https://www.snpo.org/members/Articles/Volume18/Issue5/V180534.pdf.

Rust, R. T., \& Oliver, R. L. (1994). Service quality: insights and managerial implications from the frontier. In Service quality: New directions in theory and practice (pp. 241-268).

Sandada, M., \& Matibiri, B. (2016). An Investigation into the Impact of Service Quality, Frequent Flier Programs and Safety Perception on Satisfaction and Customer Loyalty in the Airline Industry in Southern Africa. South East European Journal of Economics and Business, 11(1), 41-53. https://doi.org/10.1515/jeb-2016-0006.

Schnebelen, S., \& Bruhn, M. (2018). An appraisal framework of the determinants and consequences of brand happiness. Psychology \& Marketing, 35(2), 101-119. https://doi.org/10.1002/mar.21073

Sindwani, R., \& Goel, M. (2015). The Impact of Technology based Self Service Banking Service Quality on Customer Loyalty. International Journal of Marketing and Business Communication, 4(3), 15-22. https://doi.org/10.21863/ijmbc/2015.4.3.013.

Smales, L. A. (2020). Investor attention and global market returns during the COVID-19 crisis. International Review of Financial Analysis, 73. https://doi.org/10.1016/j.irfa.2020.101616.

Stock, M. R., Jong, A. de, \& Zacharias, N. A. (2016). Frontline Employees' Innovative Service Behavior as Key to Customer Loyalty: Insights into FLEs' Resource Gain Spiral. Journal of Product Innovation Management, 34(2), 223-245. https://doi.org/10.1111/jpim.12338.

Su, D. N., Nguyen-Phuoc, D. Q., \& Johnson, L. W. (2019). Effects of perceived safety, involvement and perceived service quality on loyalty intention among ride-sourcing passengers. Transportation. https://doi.org/10.1007/s11116-019-10058-y.

Sugiyono. (2019). Meode Penelitian Kuantitatif Kualitatif dan R\&D (2nd ed.). Alfabeta.

Torres, E. N., Fu, X., \& Lehto, X. (2014). Examining key drivers of customer delight in a hotel experience: A cross-cultural perspective. International Journal of Hospitality Management, 36, 255-262. https://doi.org/10.1016/j.ijhm.2013.09.007.

Torres, E. N., \& Kline, S. (2006). From satisfaction to delight: a model for the hotel industry. International Journal of Contemporary Hospitality Management, 18(4), 290-301. https://doi.org/10.1108/09596110610665302.

Ul Haq, I., \& Awan, T. M. (2020). Impact of e-banking service quality on e-loyalty in pandemic times through interplay of e-satisfaction. Vilakshan - XIMB Journal of Management, 17(1), 39-55. https://doi.org/10.1108/xjm-07-2020-0039.

Wang, X. (2011). The Effect of Unrelated Supporting Service Quality on Consumer Delight, Satisfaction, and Repurchase Intentions. Journal of Service Research, 14(2), 149-163. https://doi.org/10.1177/1094670511400722.

Wattanakamolchai, S., Singal, M., \& Murrmann, S. K. (2016). Socially Responsible Customers and the Evaluation of Service Quality. Journal of Hospitality \& Tourism Research, 40(6), 715-738. https://doi.org/10.1177/1096348014525635. 